\title{
Assessment of the Climatological Hazards On Some Archaeological Sites in El Minya Governorate
}

\author{
Mohamed E. Hafez*
}

\begin{abstract}
El Minya lies in arid region, it lies between the Upper and maritime links between them, which make them affected by the Mediterranean Sea in the north, and the desert of most actors. In addition to 10 mobile stations having records of Air Temperature, Surface Wind and relative humidity at Archaeological sites in El Minya, the records of two meteorological stations in El Minya were used to carrying the study, most data a period covered of 30-50 years. The study deals with the nature of the climate hazards that affect archaeological sites as a result of changes in the elements of climate. The most serious of these changes because of the resulting risk on archaeological sites, lead to blur the functional elements in the walls, also water leaks from ceilings damages hieroglyphic inscription, in addition at exposed archaeological sites under the effect of wind, rainfall and flood. The study concluded that Climatic phenomena contribute a major role in causing of exacerbating the effects of extreme events on Archaeological sites in El Minya. The outcomes of such events arise in many zones from climate conditions and processes that to Archaeological sites differently exposed or surrounding areas and either limit or enhance their ability to appropriately respond to and recover from hazardous events or conditions. Conclude study that the impact of flood in eastern archaeological sites, and impact of sandstorms in western archaeological sites, and come erosion (rain and Wind) in second place in terms of impact in most of the archaeological sites in El Minya.
\end{abstract}

Key Words: Assessment, Climatic Changes, Climatological Hazards, Archaeological sites, El Minya Governorate.

\section{Introduction}

El Minya Governorate is a museum, representing the old records of history, as it is a full record of the archaeology of the Pharaonic, RoMinyan, Greek, Coptic and Islamic cultures. Archaeological sites have been subjected to physiographic modifications. Most of them have been caused by climatological hazards; Archaeological sites degradation is widespread because of hazardous consequences. The potential impacts of climate on

* Assistant Professor of Applied Climatology, Department of Geography \& GIS, Faculty of Arts, Helwan University.

$-49-$ 
archaeological sites are significant, ranging from direct effects such as temperature and erosion, to indirect influences including changes in weathering. We recognize that climate is only one aspect of the geoenvironmental hazardous on archaeological sites in El Minya. To clearly understand the essential dimensions of climatological hazards, it is necessary to contemplate air temperature (Mean annual number of days with maximum and minimum air temperature). Annual means of daily relative humidity, Wind direction and speed, maximum 24 hour rainfall amount, and also flash floods and sand storms.

\section{Study Area}

The study area is located nearly in the middle of Egypt, between Latitude $27^{\circ} 35^{\prime}$ and $28^{\circ} 45^{\prime} \mathrm{N}$ and occupies the third zone among the governorates of Egypt in terms of archaeological value, where the total number of archeological sites in the province is $\mathbf{5 4}$ archaeological sites. In this study, six archaeological sites have been selected, which include El Ashmoneen, Tal El-Amarna, El Bahnasa, Beni Hassan, El Sheikh Abada and Tuna El Gabel.

El Minya Governorate occupies prime location on the Nile River, covering a distance of more than $150 \mathrm{~km}$, and an average width of $17.5 \mathrm{~km}$, and is bordered to the north by Beni Suef Governorate, on the south Assiut Governorate, and extend its borders Eastward to the borders of the Red Sea Governorate and is bordered to the west of Giza Governorate, with a total area is about $32279 \mathrm{~km}^{2}$.

\section{Archaeological Sites (Background)}

Beni-Hassan: The rock tombs of Beni-Hassan lie on the Eastern edge of the desert, on the Eastern bank of the Nile, about $23 \mathrm{~km}$. South of Minya and 35 $\mathrm{km}$, North of Tal El-Amarna. The tombs were constructed during the Middle Kingdom $\left(11^{\text {th }}\right.$ and early $12^{\text {th }}$ Dynasties) for princes and dignitaries of the Oryx or Antelope Nome, the 16th Nome of Upper Egypt (Bard, 2008).

El Ashmoneen: In the surroundings of Mallawi, about $10 \mathrm{~km}$ North, at the village of El Ashmoneen, are the extensive ruins and mounds of rubble, (Coptic Shmun; "the City of the Eight Deities"). At the North there are ruins of a temple built by Philip Arrhidaeus, Alexander the Great's half-brother, and to the North-west are extensive remains of a Nineteenth Dynasty Temple, founded by Ramesses II (Kessler, 2001).

El-Bahnasa: is a district on the Ibrahimia canal located about 50km North of Minya. Around $1.5 \mathrm{~km}$ South West of this district is the village of El- 
Queis in ancient Egypt Kais. Among the important Islamic monuments in El-Bahnasa are: The mosque of El-Hassan Ibn Saleh, minaret of the mosque of Abu-Samra (Evetts, 2001).

Tal El-Amarna: On the Eastern bank of the Nile. The site of "Tal ElAmarna", with its rock tombs and other remains, lies some $9 \mathrm{~km}$ Southeast of Mallawi at the mouth of a valley on the eastern bank of the Nile. This is all that is left of the city of Akhetaten "Horizon of the Aten", the new capital founded by Amenophis IV, who later took the name of Akhenaton, and dedicated it to the Aten or Sun god (Arnold, 2003).

Tuna El-Gebel: The necropolis of Tuna El-Gebel lies seven km South of El Ashmoneen, under the western desert plateau $(56 \mathrm{~km}$ southwest of Minya). It is the burial place of Hermopolis, also called Hermopolis West. Here are a number of tombs, dating from the Ptolemaic Period; the most notable is the splendid monument of Petosiris, the high priest of god Thoth, which resembles a small temple (Verreth, 2008).

El-Sheikh Abada: is located on the eastern bank of the Nile about $30 \mathrm{~km}$ to the east. The South of Minya, contains monuments dating from the reign of Ramses II. Here also are the remains of the Roman town of Antinoupolis (or Antinous), built in the year 130 A.D. by the Roman emperor Hadrian in memory of his favorite cupbearer Antinous (Baines and Malek, 2000).

\section{Previous Studies}

Climatological hazards on the archaeological area received great attention as one of the important issues addressed by a range of disciplines to study and analyze; where awareness of climatological hazards including the phenomenon under study began at the international level such as the study by Sander (2005). This paper aims at showing the relevance of archaeological data in constructing such a long-term history of such dynamics, and illustrating a case study as how one may identify the component processes of environmental change from archaeological materials. Joseph (2006) reviews research about impacts of environmental change on hydrological processes of relevance to preservation of archaeological remains in situ study. Carlota et al. (2007) aims to predict the evolution in freezing processes due to climate change during the $21^{\text {st }}$ century and the potential damage to historic structures and archaeological remains in Europe. Ganor et al. (2009) deals with differentiating recent artifacts from those of antiquiy and Archaeological materials that are exposed to local environmental processes. 
Some studies have also addressed the problem of climatological hazardous, but without sufficient detail, including a study by: Xunming (2007) which dealt with some of the mobile sand dunes that have been developed on the margins of active deserts which were replaced by semianchored or moored in the arid and semi-arid areas in northern Chin. Another study (Benito et al., 2008) dealt with transportation Systems by westerly airflow over the Mediterranean Sea and its relation to the floods and heavy rainfall. A study (Lioubimtseva \& Henebry, 2009) dealt with the concepts of vulnerability, adaptation, and mitigation in the context of climate change in Central Asia. Moreover some studies focused on certain aspects such as a study (Eissa and El-Ashmawy, 2009) which dealt with the Characteristics of severe Dust Storms over Egypt, and another study (ElBayomi, 2012) which examined Geomorphological Hazards in selected archeological sites in El Minya Governorate.

\section{Objectives}

The objective of this study is to provide estimates that are most needed for the potential impacts of climate and climatological hazards to which areas of archaeological of El Minya Governorate are exposed. And the evaluation aims to help acquisition of knowledge on climatic hazards faced by the archaeological sites, to determine the degree of risk to what has been monitored and studied so that it can be ranked, and to avoid negative repercussions to preserve archaeological heritage.

\section{Methodology}

Data records of ten mobile stations in a form of air temperature, surface wind and relative humidity at the studied archaeological sites were used besides data from two meteorological stations in El Minya in preparing this study (Table 1). Data of 30-50 years were used. Software has been used in the current study to facilitate the data sorting, processing and analysis. The methods of collection included the following:

- Calculation the monthly average of climate elements of the in boundary layer and Isolines maps of climate elements in each season, using program surfer and Arc Map, in addition to charts of the surface wind affecting archaeological sites in El Minya Governorate.

- Investigation some severe weather phenomena such as dust storm, sand storm and thunder storm associated with decrease visibility and strong wind. We calculate the frequency of occurrence of severe weather per 
month in different seasons and maps of distribution of occurrence of dust storm over archaeological sites in El Minya using surfer software.

- Field measurements, Geographic Information Systems (GIS) have been employed to assess the impact of climatological hazard at the archaeological sites in El Minya governorate.

Table 1. Geographical locations of monitoring stations used in the study.

\begin{tabular}{|l|l|l|l|l|}
\hline \multicolumn{1}{|c|}{ Station } & \multicolumn{1}{|c|}{$\begin{array}{c}\text { Archaeological } \\
\text { site }\end{array}$} & $\begin{array}{c}\text { Station } \\
\text { Kind }\end{array}$ & $\begin{array}{c}\text { Latitude } \\
\text { (N) } \\
\text { Decimal } \\
\text { degrees) }\end{array}$ & $\begin{array}{c}\text { Longitude } \\
\text { (E) } \\
\text { (Decimal } \\
\text { degrees) }\end{array}$ \\
\hline Minya & Minya city & synoptic & 28.08333 & 30.73333 \\
\hline Malawi & Malawi centre & synoptic & 27.70000 & 30.75000 \\
\hline Northern Domes & El Bahnasa & mobile & 28.53515 & 30.65783 \\
\hline Southern Domes & El Bahnasa & mobile & 28.53473 & 30.65130 \\
\hline Minaret Abu Samra & El Bahnasa & mobile & 28.53745 & 30.65840 \\
\hline Cemetery Betozers & Tuna El Gabal & mobile & 27.73667 & 30.70427 \\
\hline Garden Museum & El Ashmoneen & mobile & 27.78563 & 30.79920 \\
\hline Temple & El Sheikh Abada & mobile & 27.80748 & 30.87295 \\
\hline Area cemeteries & Bani Hasan & mobile & 27.92797 & 30.87363 \\
\hline Southern Cemeteries & Tel El Amarna & mobile & 27.61083 & 30.91448 \\
\hline Northern Cemeteries & Tel El Amarna & mobile & 27.66933 & 30.92080 \\
\hline Cemetery of Kings & Tel El Amarna & mobile & 27.62407 & 30.98383 \\
\hline
\end{tabular}

Source: Egyptian Metrological Authority \& Field measurements.

\section{Discussion}

\section{Climatic Characteristics:}

Maps interpretation has revealed the following points:

The mean annual sunshine duration is about 10 hours in south El Minya, and about 9 hours in El Bahnasa and cemeteries of Bani Hassan and Tal El Amarna. Features of the daily air temperature in El Minya can be summarized as follows: This distribution reflects the general features of the maximum and minimum temperature distribution. The continent is less affected during winter, where northern parts of El Minya are characterized by the lowest values of temperature during this season. The temperature gradient near Minya and Malawi is very strong from April to August and very weak from November to February (Figures 1 and 2). 

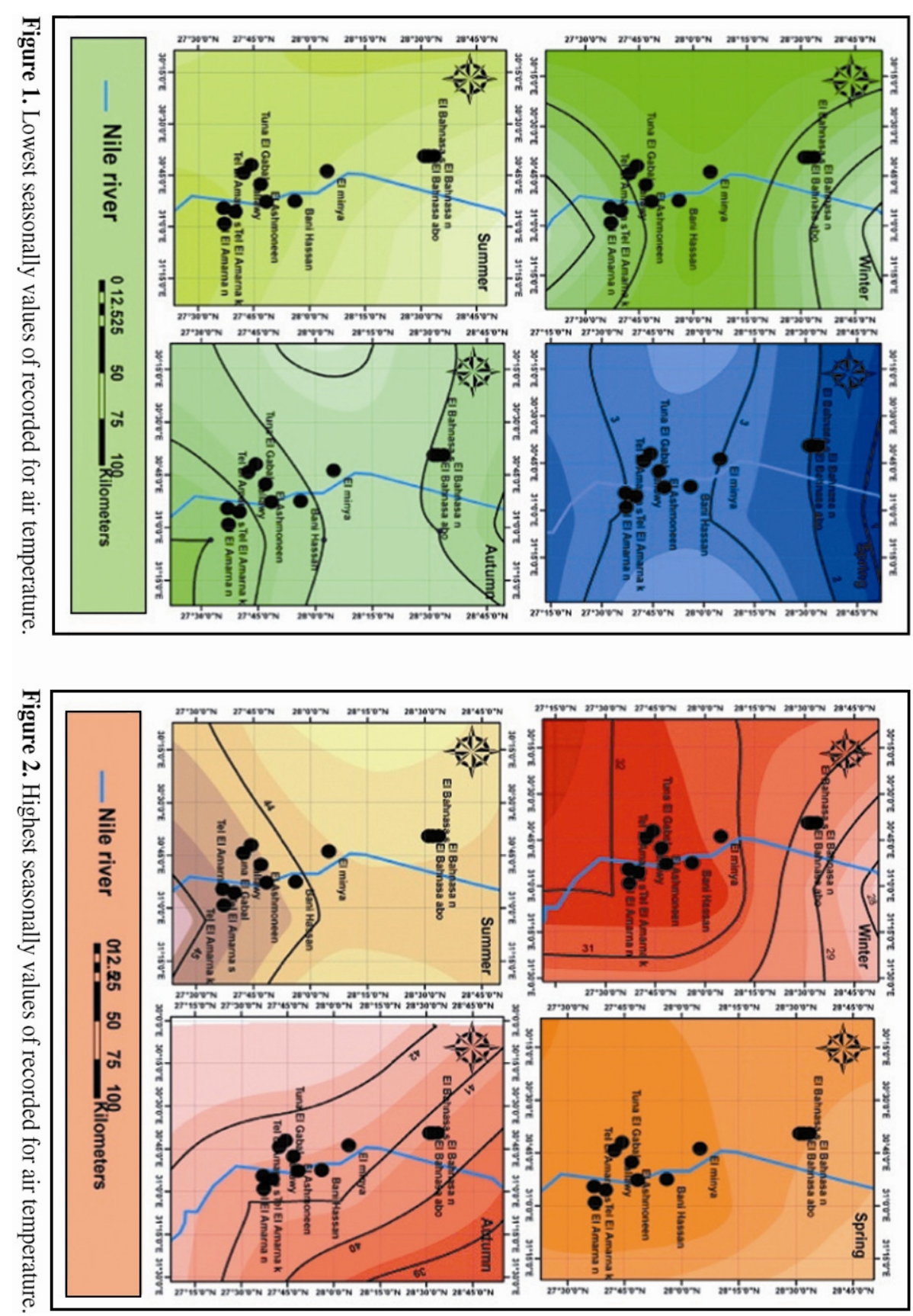

-54- 
Wind is characterized by variable directions in the different seasons. During the winter season, southern winds prevail with a velocity reaching 13 $\mathrm{m} / \mathrm{sec}$. In the spring, Khamasin winds are also common with a velocity reaching $30 \mathrm{~m} / \mathrm{sec}$. In summer, northern winds prevail with a velocity of the order of $25 \mathrm{~m} / \mathrm{sec}$. In autumn, northern and northwestern winds prevail. In September, there are mainly winds of northern and northwestern directions, while in January, there are winds of southwestern direction. As intensity and velocity of these winds are greater than those during the winter season, they have determined the direction of the existing dunes, and movement of sand masses in the sand dune area from the western desert towards the archaeological sites (Figure 3).

El Minya extends on along the Nile River a distance of almost 135 $\mathrm{km}$, the northern zones characterized by the highest values of relative humidity $(>70 \%)$. It decreases gradually southwards until it reaches its lowest value over the southern parts $(>40 \%)$, especially in late spring and during summer (Figure 4). Precipitation over El Minya is usually associated with unstable weather conditions due to the invasion of cold air masses in the upper atmosphere and low pressure troughs in the lower atmosphere. The rainy season in El Minya extends from autumn to spring. Maximum precipitation occurs during winter due to the passage of the Mediterranean depressions. However the north of El Minya is distinguished by maximum precipitation rapidly becoming too rare in the south of El Minya and Western desert.

Palaeoclimate evidence and archaeological data indicate that the climate of arid at El Minya district has experienced many past fluctuations that might be comparable with present and future climate change. Based on the early-to-mid-Holocene reconstructions, the arid zones of El Minya may become moister as a result of global warming, due to an expected southward shift and probable intensification of the westerly cyclones (Lioubimtseva, 2009).

\section{Climatological Hazard:}

Climate events, those originating from extreme and common climatic processes, are referred to as climatic hazards: Floods, Hurricanes, Blizzards, Sandstorms and Tornadoes that originate in atmosphere are some examples of climatic hazards. The analysis and interpretation of maps have revealed the following points: 

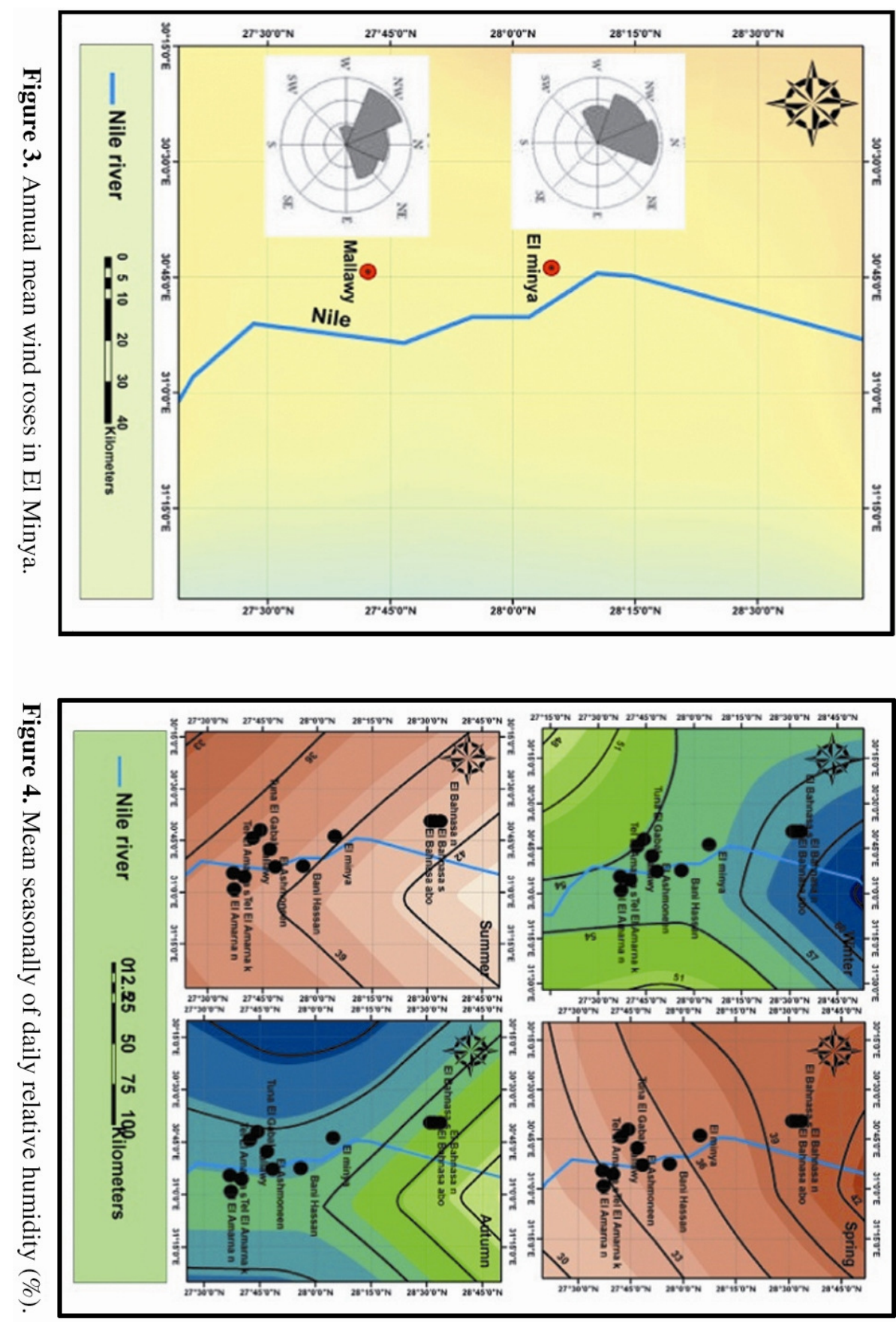

$-56-$ 
* The maximum air temperature $>35{ }^{\circ} \mathrm{C}$ reaches its highest value at the south in Tal El-Amarna site (Figure 5). The lowest temperature values are recorded at El Bahnasa site. There is a large decrease in temperature during night due to intense radiation cooling. The lowest values all over El Minya appear in the East at the cemeteries of Bani Hassan site.

* The feature is also recorded at El-Ashmoneen and Tuna El Gabal where the minimum temperature is $<5{ }^{\circ} \mathrm{C}$, contrary to the maximum temperature $>$ which is $35^{\circ} \mathrm{C}$. It is clear that the temperature range varies daily and seasonally from day to night as well as from summer to winter which represents gradual effects on archaeological sites in El Minya (Figure 6). The effects of high air temperature are reflected in rises of the amount of evaporation from the Nile River and agriculture lands which lead to the increase of air humidity, e.g. at Bani Hassan and Tal El-Amarna archeological sites.

* The maximum 24 hours rainfall at the east side of the Nile valley is concentrated in the north of the study area, especially the east of Nile River, and rapidly decreases southward to Bani Hassan (Figures 7 and 8). During autumn and spring, heavy unstable conditions occur at the east of El Minya when upper air cold troughs reaching across north Egypt from Europe, co-related with northern extension of the Sudan Monsoon depression. The instability increases over the Red Sea Mountains due to topographic relief effects causing thunderstorms and heavy showers and sometimes it extends to El Sheikh' Abadah, Bani Hassan and Tel El Amarna archeological sites. These heavy storms can cause flash floods in some locations of the archeological sites.

* A flash flood usually occurs due to cold air outbreaks over a preheated mountainous land. The torrential rains resulting from such weather conditions accumulate in catchment areas at the top of mountains. At a critical situation, the water is released from a vulnerable part of the catchment area running towards the Nile valley, acquiring a great momentum during its long path along the mountains, carrying coarse materials causing a huge damage to the surrounding areas in the Nile valley. 

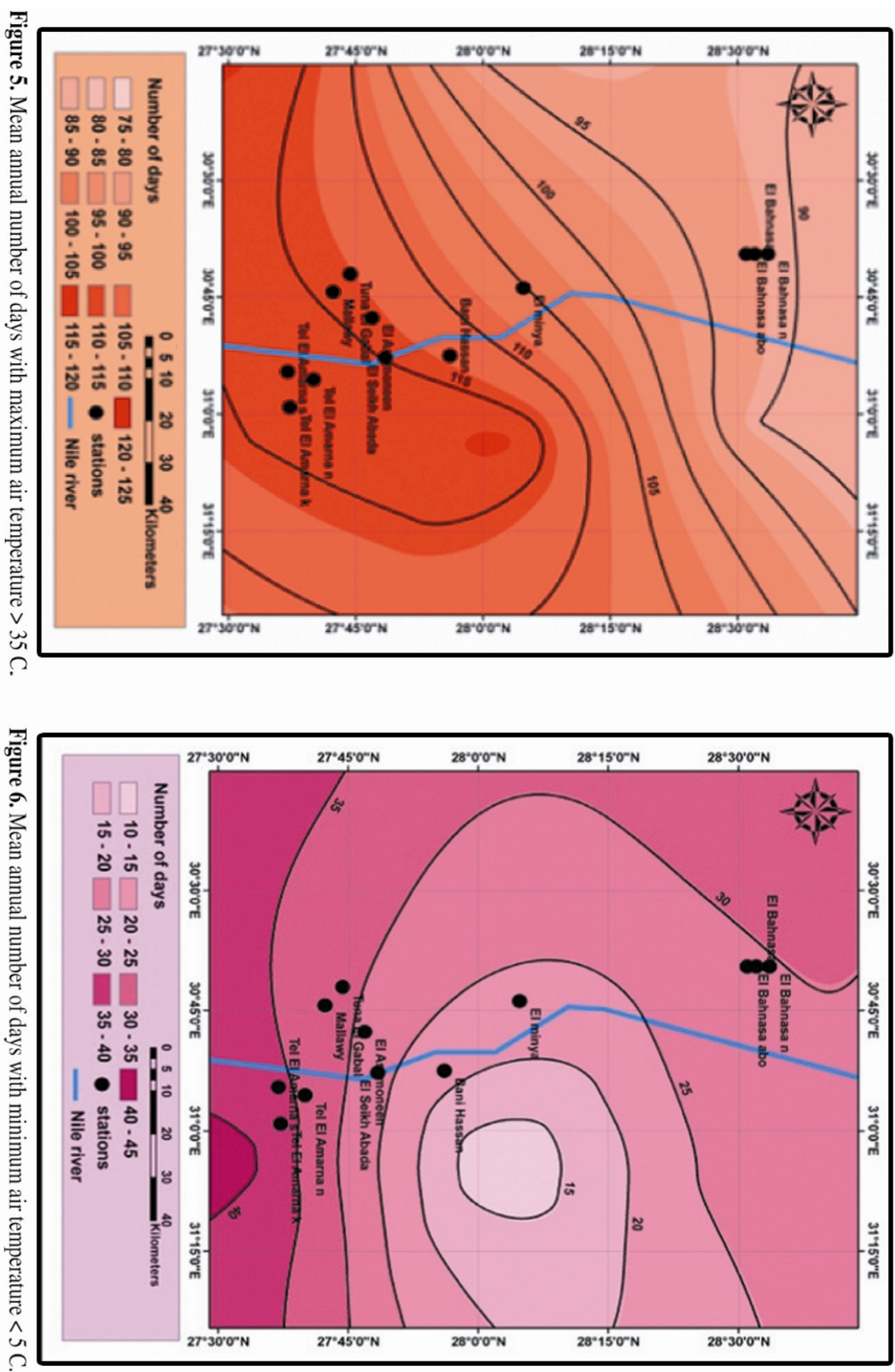

$-58-$ 

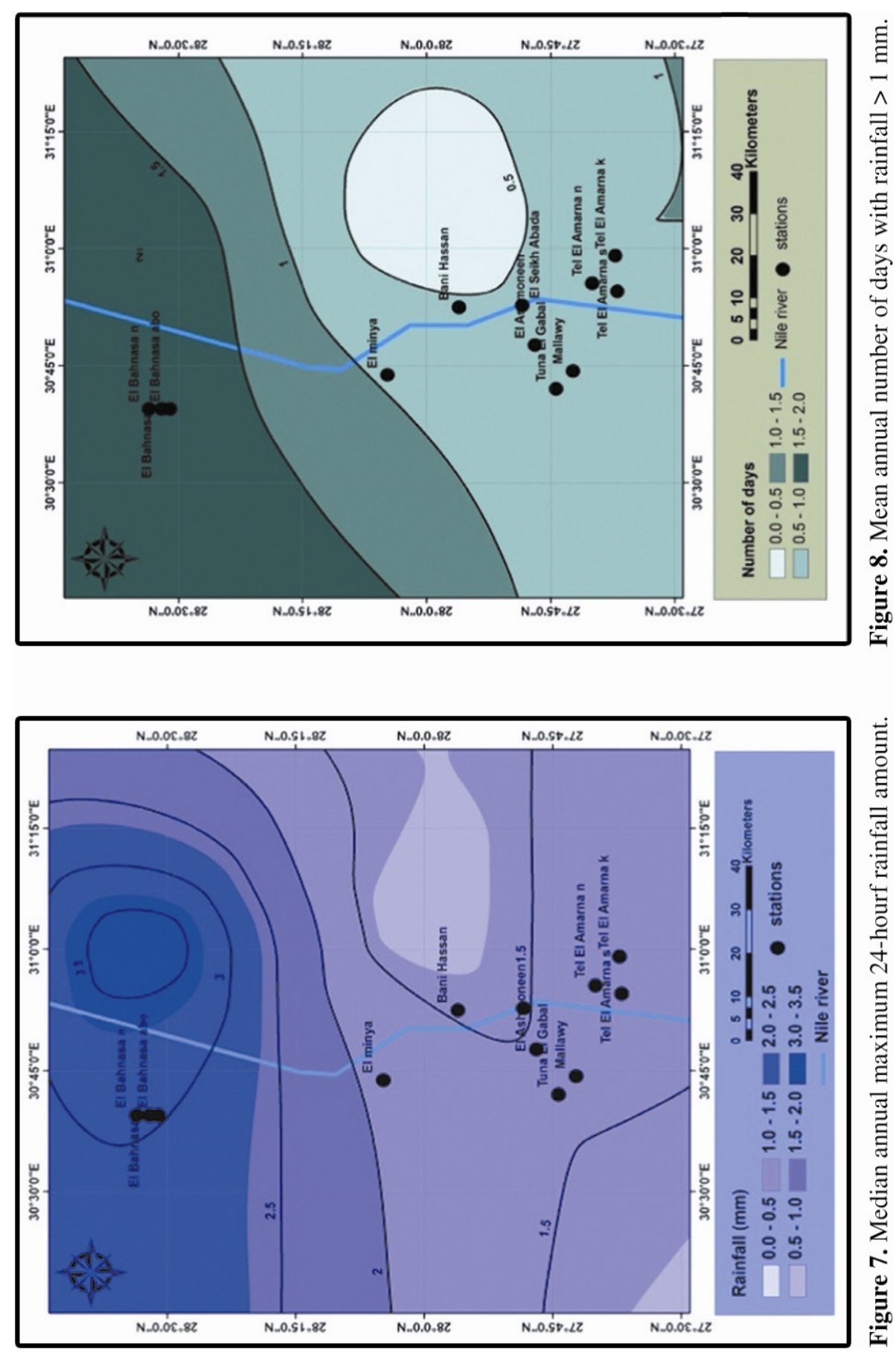

泀

-59- 
* The catchment area of wadi El Omrani, wadi Abou hasha El Qibly, wadi El Bahary and wadi Ibada which discharge directly at the eastern archeological sites were calculated in the morphometric section. Autumn is considered the season of highest frequency of occurrence of flash floods in El Minya district due to the invasion of cold air masses into the preheated mountainous area after a very long hot summer such as the severe synoptic situations in El Minya and Mallawi, which occurred in autumn 1992 and spring 2014. These situations caused severe flash floods over eastern El Minya especially the valleys which drain from the Red sea hills (Figure 9). The results of the study show that flash floods over central Red Sea were caused mainly by the northern oscillations of the Sudan monsoon low.

* The sand storm phenomenon occurs over El Minya during autumn and spring. The frequency of occurrence of sand storms during spring is higher than autumn (Figure 10). The sand storms usually happen due to the passage of a thermal surface depression (Khamasin type) associated with a strong subtropical jet stream at the upper troposphere. This thermal depression is sporadically formed over the Egyptian desert near to the coast due to conditions of differential heating between the Egyptian desert and the surface of the Mediterranean Sea. It can persist for several days and is characterized by its fast movement from west to east and the associated strong surface winds that can carry the sand aloft.

* These are significant weather phenomena affecting all archaeological sites especially in study areas. In El Minya severe storms such as Dust, Sand and Thunderstorms phenomena are considered to be the most striking weather hazard in different seasons, not to mention Thunderstorms with heavy rain especially in winter and early spring and late autumn. Dust and Sand are raised from the ground by the wind and carried upward depending on meteorological conditions and the state of the soil including the size of particles.

\section{Archaeological Sites Degradation:}

There is evidence in the archaeological sites on the impact of aerobic processes like deposition (ripples and dunes), wind speed and turbulence blowing in the form of circular currents; they have also an impact on carving archaeological sites. From the field survey, the interaction between materials carried by the wind and most of the archaeological sites in the study area is clearly observed (Photo 1). At El Bahnasa, this factor appears clearly in 
Minaret Abu Samra and the Greek column (Photo 2). At El Sheikh' Abadah, the effects of wind erosion are completely shown in the remaining columns of Ramses II temple (Photo 3). Wind erosion affects the soft formations of limestone rocks faster than the hard rocks such as basalt; it is typically composed largely of plagioclase with pyroxene and olivine. These land forms appear as piles, grooves and small caves in the exterior walls of Beni Hassan and Tal El-Amarna tombs (Photo 4)

Rainfall leads to detachment of soil particles from surface and breakingup of soil aggregates. Then infiltration will lead to local transport of small particles and soil aggregates from pore spaces accompanied by increase of erosion process (Photo 5). Monthly rainfall data of two meteorological stations were collected for the years 1976-2005 (Table 2).The water erosion factor (MC) was calculated in terms of metric tons per $\mathrm{km}^{2}$. Evidence of rainfall was noted during the field study as shown in mud crack at ElSheikh' Abadah site. Also, traces from rain water were also shown in the roofs of the tombs at Beni Hassan like Meri-Ra tomb (Photo 6). This rain water contributes directly or indirectly to the deterioration process of different monumental objects of the studied archaeological sites.

Table 2. Water erosion factor (MC) as determined from El Minya and Mallawi climatological normal.

\begin{tabular}{|l|c|c|c|c|}
\hline \multirow{2}{*}{ Months } & \multicolumn{2}{|c|}{ El Minya } & \multicolumn{2}{c|}{ Mallawi } \\
\cline { 2 - 5 } & $\begin{array}{c}\text { Rainfall } \\
\text { (mms.) }\end{array}$ & MC & $\begin{array}{c}\text { Rainfall } \\
\text { (mms.) }\end{array}$ & MC \\
\hline January & 1,1 & 1,21 & 2,1 & 4,41 \\
\hline February & 1,7 & 2,89 & 1,6 & 2,56 \\
\hline March & 3,4 & 11,56 & 1,6 & 2,56 \\
\hline April & 0,5 & 0,25 & 0,6 & 0,36 \\
\hline May & 1,4 & 1,96 & 0,3 & 0,09 \\
\hline June & 0 & 0 & 0 & 0 \\
\hline July & 0 & 0 & 0 & 0 \\
\hline August & 0 & 0 & 0 & 0 \\
\hline September & 0 & 0 & 0 & 0 \\
\hline October & 0 & 0 & 0,2 & 0,04 \\
\hline November & 3,5 & 12,25 & 3,2 & 10,24 \\
\hline December & 2,1 & 4,41 & 1 & 1 \\
\hline \multicolumn{1}{|c|}{ Total } & $\mathbf{1 3 , 7}$ & $\mathbf{3 4 , 5 3}$ & $\mathbf{1 0 , 6}$ & $\mathbf{2 1 , 2 6}$ \\
\hline factor C & & $\mathbf{2 , 5 2 0 4 3 8}$ & & $\mathbf{2 , 0 0 5 6 6}$ \\
\hline
\end{tabular}

Source: Eissa, 2011, P. 14. 

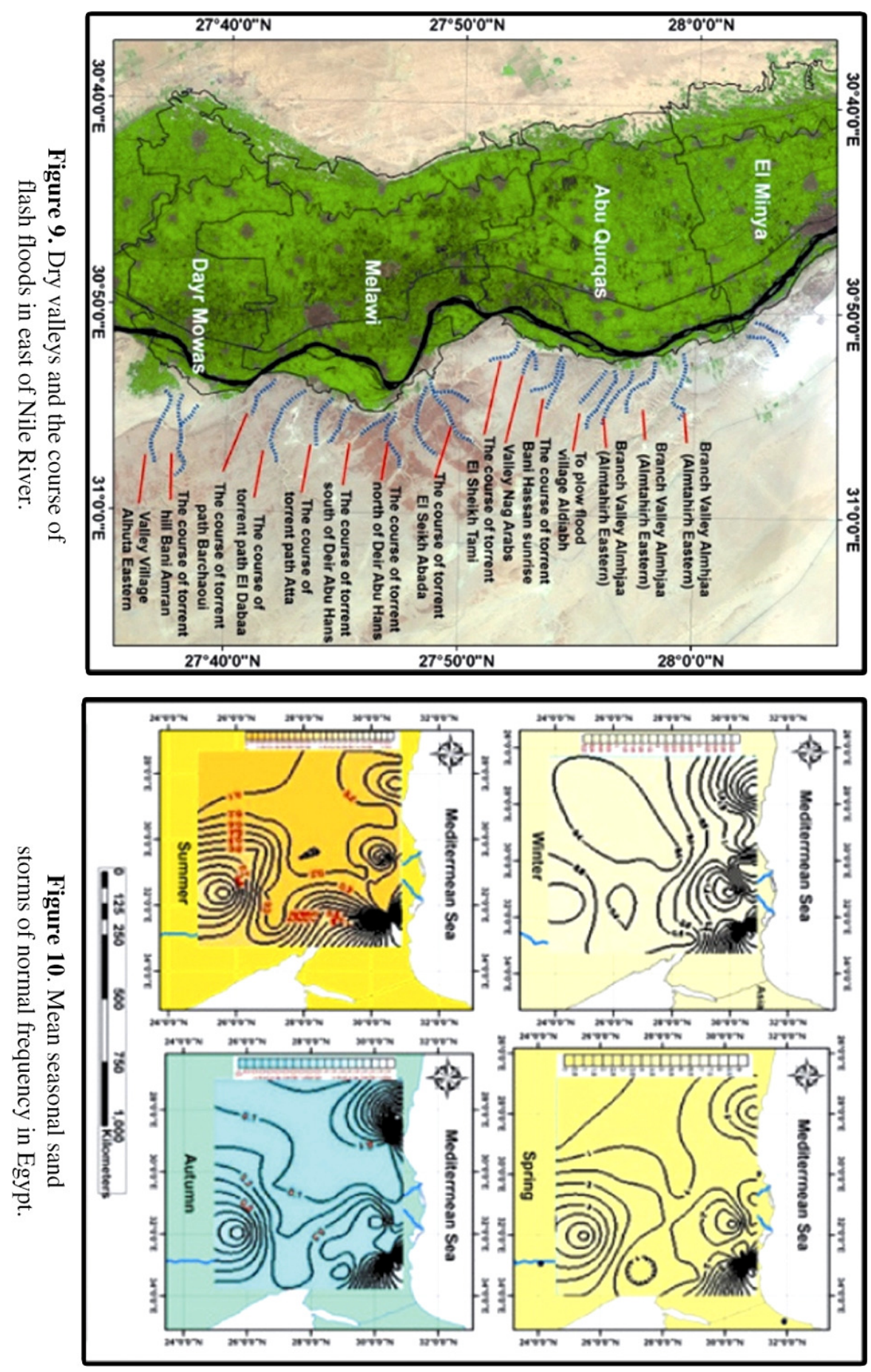

$-62-$ 


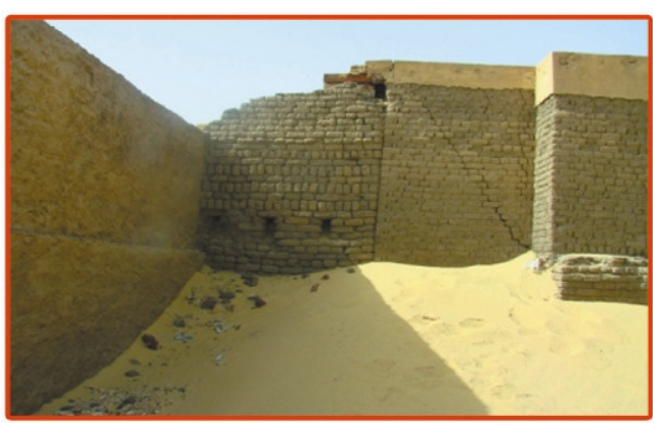

Photo 1. Failure and cracks in the walls catch tomb at Tuna El Gabal as a result of wind erosion on the foundation.

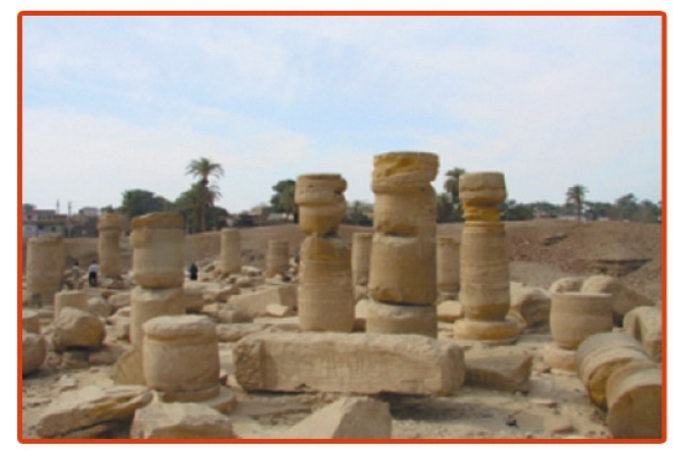

Photo 3. Effect of wind on remaining columns of Ramses II temple at El -Sheikh' Abadah site.

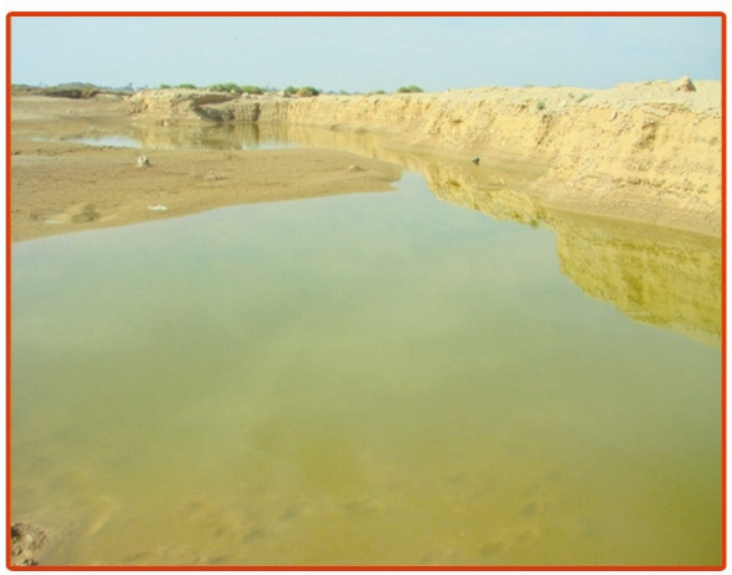

Photo 5. Traces from recent flash flood during field trip at 2013, inside Wadi Abadah.

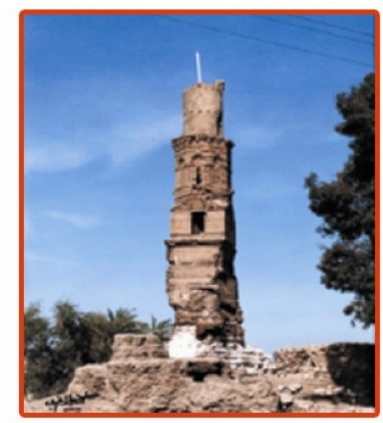

Photo 2. Effect of wind erosion at El Bahnasa site (Minaret Abu Samra).

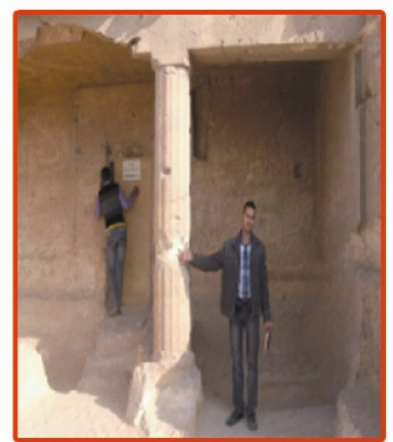

Photo 4. Wind pits in the exterior walls of Bani Hassan as a result of erosion.
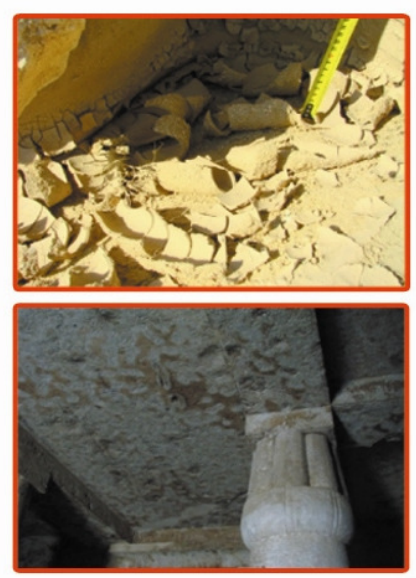

Photo 5. Effect of rain water at the ceiling and inside tombs at Bani Hassan. 


\section{Classification of Climate Hazards:}

Climatic hazards can be further categorized into atmospheric hazards (typically weather-related) such as tropical storms, cyclones such as hurricanes, and thunderstorms, tornadoes, lightning, hailstorms, windstorms, ice storms, snowstorms, sandstorms, blizzards, cold waves, heat waves, avalanches, fog, frost, floods and droughts. Based on the nature of the physical processes involved, Tobin and Montz (1997) classified climatic hazards in archaeological sites in El Minya into four categories: thunderstorms, sandstorms, erosion (wind-rainfall) and flash floods. Climatic hazards often vary spatially, even seasonally, and they also frequently trigger secondary hazards. For example, severe storms may follow flash floods. Thunderstorms may be accompanied by heavy rains that can cause soil erosion and conventional flooding. That hazard, depending on time of initiation, can be a primary or secondary hazard. All of which can cause a considerable damage to archaeological sites in El Minya. As shown in Figure (11), the focus of this part is on climatic hazards.

From Table (3), it is possible to conclude that the flash floods are ranked first with respect to the negative impact on archaeological sites in the east of the Nile River, sandstorms are ranked first in the archaeological sites in the west of the Nile River, and erosion (rain and wind) is the second in most of the archaeological sites in El Minya, While there is a lack of the impact of flash floods and erosion rain in most of the western archaeological sites of the Nile River.

\section{Implement measures to mitigate the impacts of climatic hazards:}

Strategies adopted to cope with hazards can be classified in two different ways: by making a distinction between indigenous and modern coping mechanisms, as well as between those strategies adopted purposefully and those which are incidental. A comprehensive survey of the areas and storm water drains, and determining the stationing sites of special equipment for emergence is an example of an indigenous coping strategy, while the flood warning system introduced earlier by the government in this Archaeological sites can be considered a modern coping strategy. Ways for protection the climatic hazards:

- Protection from wind erosion: A forestation limits of sites, particularly in the direction of the oncoming wind act as windbreaks to protect archaeological sites from the exposed sandy places. 
- Protection from rain erosion and flash floods: Establishment of a network of rain and drainage networks, so they do not gather around archaeological sites, and descend away from them and pour in the Nile River.

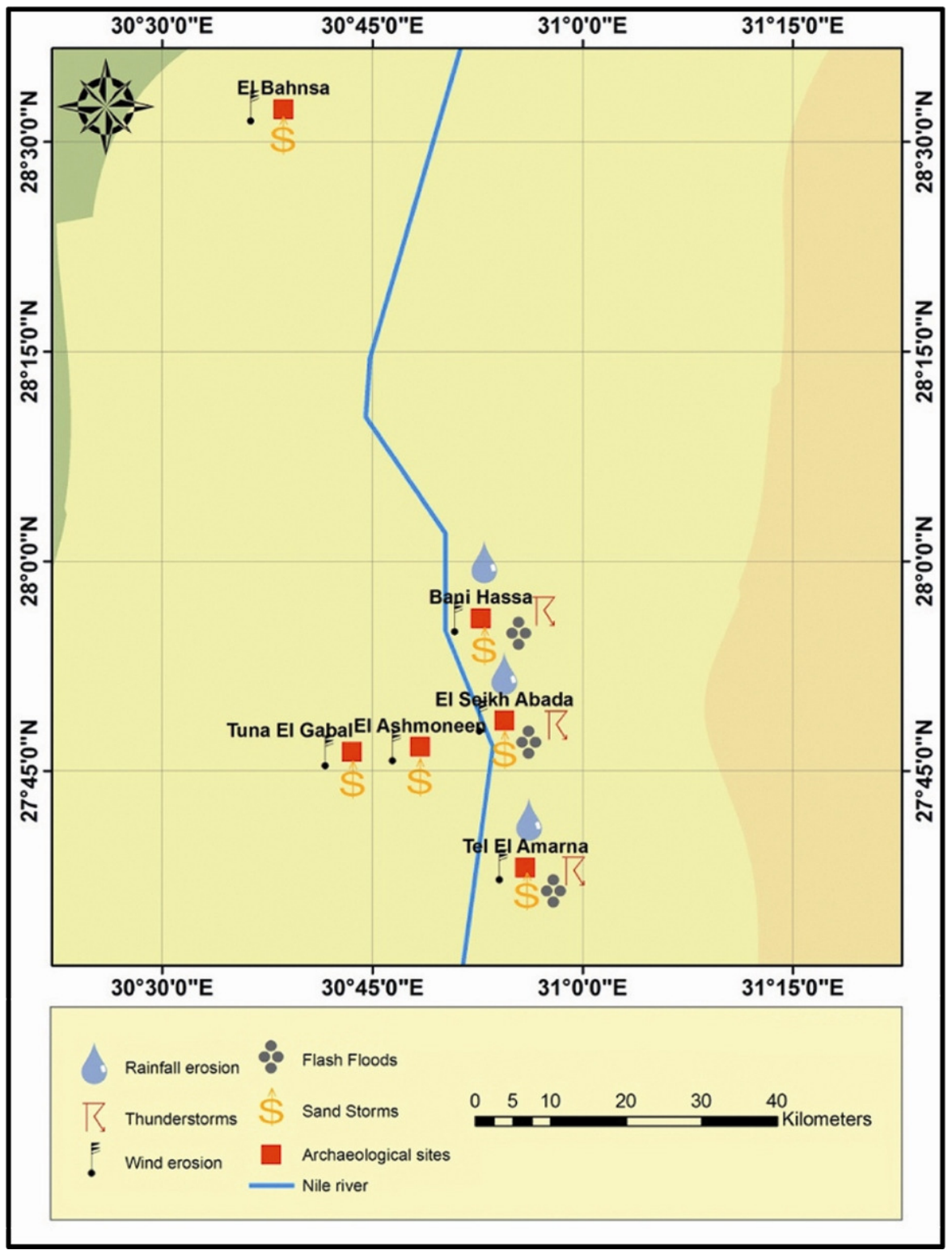

Figure 11. Types of climate hazards in archaeological sites in El Minya.

$-65-$ 
Table 3. Degrees of risk at archaeological sites in El Minya Governorate.

\begin{tabular}{|c|c|c|c|c|c|c|}
\hline No. & Location & Climatic hazards & \multicolumn{4}{|c|}{ Degrees of risk } \\
\hline \multirow{5}{*}{1} & \multirow{5}{*}{ Tal El- Amarna } & Rainfall erosion & & & 2 & \\
\hline & & Wind erosion & & & 2 & \\
\hline & & flash floods & & & & 3 \\
\hline & & sandstorms & & & 2 & \\
\hline & & thunderstorms & & 1 & & \\
\hline \multirow{5}{*}{2} & \multirow{5}{*}{ Bani Hassan } & Rainfall erosion & & & 2 & \\
\hline & & Wind erosion & & & 2 & \\
\hline & & flash floods & & & & 3 \\
\hline & & sandstorms & & & 2 & \\
\hline & & thunderstorms & & 1 & & \\
\hline \multirow{5}{*}{3} & \multirow{5}{*}{ El Seikh Abada } & Rainfall erosion & & & 2 & \\
\hline & & Wind erosion & & & & 3 \\
\hline & & flash floods & & & 2 & \\
\hline & & sandstorms & & & 2 & \\
\hline & & thunderstorms & & 1 & & \\
\hline \multirow{5}{*}{4} & \multirow{5}{*}{ El Ashmoneen } & Rainfall erosion & 0 & & & \\
\hline & & Wind erosion & & & 2 & \\
\hline & & flash floods & 0 & & & \\
\hline & & sandstorms & & & 2 & \\
\hline & & thunderstorms & 0 & & & \\
\hline \multirow{5}{*}{5} & \multirow{5}{*}{ Tuna El Gabal } & Rainfall erosion & 0 & & & \\
\hline & & Wind erosion & & & 2 & \\
\hline & & flash floods & 0 & & & \\
\hline & & sandstorms & & & & 3 \\
\hline & & thunderstorms & 0 & & & \\
\hline \multirow{5}{*}{6} & \multirow{5}{*}{ El Bahnasa } & Rainfall erosion & 0 & & & \\
\hline & & Wind erosion & & & 2 & \\
\hline & & flash floods & 0 & & & \\
\hline & & sandstorms & & & & 3 \\
\hline & & thunderstorms & 0 & & & \\
\hline
\end{tabular}

Note: Zero is equal to Lack of impact, one is equal to weak impact and a low degree of risk, two is equal to medium risk, and three is equal to strong impact and a high degree of risk. 


\section{Conclusions}

- Archaeological sites in El Minya Governorate are characterized in a particular pattern, distinguished from others in the rest of the archaeological sites in the governorates of Egypt; extreme Air temperature, high Humidity and dense Rainfall are of the climate factors that affect the archaeological sites in El Minya Governorate, and still the rainfall and resulting floods, especially in the eastern side of the Nile River is the most threatening factor in sites such as Bani Hassan, El Sheikh Abadah, and Tal El-Amarna.

- This study deals with the assessment of climatic hazards in archaeological sites in El Minya, as a result of changes in the climatic elements, such as: maximum Rainfall and high Humidity. Wind erosion is the most dangerous from between those changes because of its direct risk on archaeological sites, where it cause erasing the inscriptions and drawings on the walls, the leak of water from tombs roofs damage it also, in addition to the great impact of wind erosion and flood, especially on the open archaeological sites.

- The floods are ranked first with respect to the negative impact of climate perspective in the eastern archaeological sites of the Nile River, and Sandstorms ranked first in the archaeological sites in the west of the Nile River, but erosions (rain and Wind) is ranked the second in most of the archaeological sites in Minya, while there is no impact of floods and rain erosion in the most of the western archaeological sites of the Nile River.

\section{Recommendations}

- Draw the attention of decision-makers and those interested about climate hazards that threaten the archaeological sites the Egypt as a whole.

- Intensification of scientific research on processors damage to archaeological sites as a result of climate hazards.

- Interest in the maintenance of archaeological sites by modern scientific methods of sustainability with climate change.

- Documenting all the details of the archaeological sites in order to maintain its original character if it is exposed to natural hazards. 


\section{References}

1. Arnold, D. (2003): Encyclopedia of Ancient Egyptian Architecture. Princeton University Press, ISBN 0-691-11488-9.

2. Baines, J. and Malek, J. (2000): Cultural Atlas of Ancient Egypt. Revised Edition ed. Oxford shire, England: Andromeda Oxford Limited.

3. Bard, K.A. (2008): An Introduction to the Archaeology of Ancient Egypt. Oxford, United Kingdom: Blackwell Ltd.

4. Benito, G. et al. (2008): Palaeo flood and floodplain records from Spain: Evidence for long-term climate variability and environmental changes, Elsevier B.V., Geomorphology 101: 68-77.

5. Carlota, M.G. et al. (2007): Predicting long term freeze-thaw risks on Europe built heritage and archaeological sites in a changing climate, Elsevier B.V., Science of the Total Environment 377 (2007) 273-28.

6. Eissa, M.M. (2011): Evaluation of some climatic factors for soil erosion in Egypt, Water erosion, Egyptian Meteorological Authority, Cairo.

7. Eissa, M.M. and El-Ashmawy, F.M. (2007): Characteristic of severe storms over Egypt, Egyptian Meteorological Research Bulletin Vol. 22, pp. 92-108.

8. Eissa, M.M. and El-Ashmawy, F.M. (2009): Characteristic of severe Dust Storms over Egypt, Egyptian Meteorological Authority, Cairo.

9. El-Bayomi, M.G. (2012): Geomorphological Hazards in selected archeological sites, El Minya province, Bulletin of the Egyptian geographical society, Vol. 85, 79-90.

10. Evetts, B. (2001): Churches and Monasteries of Egypt and Some Neighboring Countries. Gorgas Press, ISBN 0-9715986-7-3.

11. Ganor, E. et al. (2009): Environmental dust: A tool to study the patina of ancient artifacts, Elsevier Ltd, Journal of Arid Environments.

12. Joseph Holden, et al. (2006): Hydrological controls of in situ preservation of waterlogged archaeological deposits, Elsevier B.V., Earth-Science Reviews 78 (2006) 59-83.

13. Kessler, D. and Nur el-din, A. (2005): 'Tuna al-Gebel: Millions of Ibises and other Animals', in: S. Ikram, Divine Creatures, Animal Mummies in Ancient Egypt, The American University in Cairo press, 120.

14. Lioubimtseva, G.M. (2009): Climate and environmental change in arid Central Asia: Impacts, vulnerability, and adaptations, Elsevier Ltd, Journal of Arid Environments 73: 963-977.

15. Sander, E.V. et al. (2005): Climate, hydrology, land use, and environmental degradation in the lower Rhone Valley during the Roman period, Elsevier, C. R. Geo-science 337 (2005) 9-27.

16. Tobin, G.A. \& Montz, B.E. (1997): Natural Hazards: Explanation and integration. New York: The Guilford Press.

17. Verreth, H. (2008): A survey of Toponyms in Egypt in the Graeco-Roman period, Köln/ Leuven, Trismegistos, 597.

18. Xunming, W. et al. (2007): Significance of variations in the wind energy environment over the past 50 years with respect to dune activity and desertification in arid and semiarid northern China, Elsevier B.V., Geomorphology 86 (2007) 252266. 